\title{
The effects of shifting vegetation mosaics on habitat suitability for coastal dune fauna-a case study on sand lizards (Lacerta agilis)
}

\author{
Bart Wouters • Marijn Nijssen • Gertjan Geerling • \\ Hein Van Kleef • Eva Remke • Wilco Verberk
}

Received: 13 May 2011 /Revised: 13 November 2011 /Accepted: 16 November 2011 /Published online: 13 December 2011

(C) The Author(s) 2011. This article is published with open access at Springerlink.com

\begin{abstract}
Encroachment of tall grasses and shrubs in coastal dunes has resulted in loss of vegetation heterogeneity. This is expected to have negative effects on animal diversity. To counteract encroachment and develop structural heterogeneity grazing is a widely used management practice. Here, we aim to functionally interpret changes in vegetation composition and configuration following grazing management on habitat suitability for sand lizards. Aerial photographs taken over a period of 16 years were used to quantify changes in vegetation composition. A GISbased method was developed to calculate habitat suitability for sand lizards in a spatially explicit manner, encompassing differences in vegetation structure and patch size. From 1987 to 2003 dune vegetation shifted from small patches of
\end{abstract}

B. Wouters $(\bowtie) \cdot$ M. Nijssen $\cdot$ H. Van Kleef $\cdot$ E. Remke $\cdot$

W. Verberk

Bargerveen Foundation,

P.O. Box 9010, 6500 GL Nijmegen, The Netherlands

e-mail: b.wouters@science.ru.nl

M. Nijssen

e-mail: m.nijssen@science.ru.nl

H. Van Kleef

e-mail: h.vankleef@science.ru.nl

E. Remke

e-mail: e.remke@science.ru.nl

W. Verberk

e-mail:wilco@aquaticecology.nl

G. Geerling

Centre for Sustainable Management of Resources, ISIS,

Radboud University Nijmegen,

toernooiveld 1 ,

6525 ED Nijmegen, The Netherlands

e-mail: gertjan.geerling@science.ru.nl moss and sand to larger patches covered by shrubs and grasses. Grazing management did not have any significant effect on the overall level of heterogeneity, measured as habitat suitability for sand lizards. However, on a more local scale highly suitable patches in 1987 were deteriorating whereas unsuitable patches became more suitable in 2003. This inversion results from a broad shift with shrubs being a limiting habitat element in 1987 to sandy patches being the limiting element in 2003. Future changes are believed to negatively impact sand lizards. The habitat suitability model has proven to be a useful tool to functionally interpret changes in coastal dune vegetation heterogeneity from an animal's perspective. Further research should aim to include multiple species operating on

H. Van Kleef

Department of Environmental Science, Institute for Wetland and Water Research, Radboud University Nijmegen,

toernooiveld 1 ,

6525 ED Nijmegen, The Netherlands

B. Wouters $\cdot$ M. Nijssen $\cdot$ E. Remke $\cdot$ W. Verberk Department of Animal Ecology and Ecophysiology, Institute for Wetland and Water Research, Radboud University Nijmegen, toernooiveld 1 ,

6525 ED Nijmegen, The Netherlands

Present Address:

W. Verberk

Marine Biology and Ecology Research Centre,

University of Plymouth,

Davy Building, Drake Circus,

PL4 8AA Plymouth, UK

e-mail: wilco@aquaticecology.nl 
different scale levels to fully capture the natural landscape dynamics.

Keywords Grazing management · Restoration ecology Patch size $\cdot$ Heterogeneity $\cdot$ Remote sensing $\cdot$ GIS

\section{Introduction}

Dry coastal dune ecosystems are spatially structured, consisting of a fine scaled mosaic of patches which provide suitable habitat for many plant and animal species (De Bruyn 1997). This spatial heterogeneity arises from the interplay between aeolian dynamics, soil development and vegetation succession and the intensity of each of these processes is governed by elevation differences and spatial variation in dune slope exposure (Doing 1995; Ranwell 1972).

Dune ecosystems along the coast of North-western Europe are threatened by the expansion of tall, highly competitive grass and shrub species since the 1950s. This results in dense homogeneous vegetations with a thick litter layer (Ketner-Oostra and Sýkora 2004; Veer and Kooijman 1997). This process of grass and shrub encroachment is mainly caused by increased atmospheric nitrogen deposition (Jones et al. 2004; Kooijman et al. 1998), decreased intensity of grazing by rabbits after plagues of myxomatose and RVHD (Rabbit Viral Haemorrhagic Disease; Drees and Olff 2001; Ranwell 1963) and changes in land use practice (loss of marram harvest and agricultural use) (Provoost et al. 2009). The habitat degradation is manifested as a decrease and loss of open sand, early successional stages, small herbaceous plants and lichens, with concomitant loss of variation in microclimatic conditions (Maes and Bonte 2006; Stoutjesdijk and Barkman 1992).

Landscape heterogeneity is recognised to be an important driver for plant and animal diversity (Geerling et al. 2006; Huston 1979; Kerr et al. 2001; Verberk et al. 2006; Wiens 1989). Loss of heterogeneity threatens animal species that are characteristic for dunes by limiting their possibilities for thermoregulation, foraging and breeding (Bonte et al. 2004; Maes and Bonte 2006).

To counteract the effects of encroachment in coastal dune landscapes restoration measures are taken. Grazing is a widely used management practice in coastal dunes (Provoost et al. 2009), because it is relatively cheap and can be applied on a large scale and in undulating landscapes. A key priority aim of this type of management is the restoration and conservation of landscape heterogeneity (Hopkins and Radley 1998). Management by grazing can increase the spatial heterogeneity of the vegetation in some cases (Adler et al. 2001), but it remains unknown to what degree animals profit from such increases. In this study, we investigate how grazing by cattle and ponies in a Dutch dune area influences the vegetation and how these changes affect habitat heterogeneity from an animal's perspective. Basic properties of heterogeneity include habitat diversity (variation in patch identity) and habitat configuration (size and distances between patches) (Gusafson 1998; Verberk et al. 2006). Sand lizards Lacerta agilis are considered to be good representatives for coastal dune heterogeneity as they require a habitat with combinations of different patches for thermoregulation, foraging, hiding, hibernation and egg deposition (Edgar et al. 2010; Glandt 1991; House et al. 1980; House and Spellerberg 1983a). Sand lizards are especially interesting because they have been subject of intense debate, with many herpetologists voicing concern about the disturbing effects grazing can have when high stocking densities are applied (Edgar et al. 2010; Offer et al. 2003; Stumpel 2004). Finally, the sand lizard is a flagship species for nature management and conservation policy in coastal dunes and is listed in the EU Habitat Directive (Council directive 1992).

When investigating the relation between habitat heterogeneity and the abundance or diversity of its inhabitants, few studies analyse the influence of combinations of patch types in a spatially explicit approach, i.e. by using distance to other patch types or by using grain size of patches as variables in correlative analyses (Bonte et al. 2000; Dennis et al. 2002). As a measure of heterogeneity previous studies have used e.g., the availability or evenness of discrete structural elements (Tews et al. 2004), single vegetation variables (Pöyry et al. 2006; WallisDeVries and Raemakers 2001) or employed different classes of heterogeneity based on one or more vegetation variables (Gibson et al. 1992). In this study we focussed on the patch dynamics resulting from shifting vegetation mosaics in Dutch coastal dunes from a sand lizard's perspective. To this end we developed a spatially explicit GIS model to assess habitat suitability for the sand lizard. To functionally interpret changes in dry coastal dune heterogeneity for fauna, we (a) investigate changes in vegetation heterogeneity in grazed and ungrazed plots over a 16 year period, (b) determine the impact of these vegetation changes on habitat suitability for sand lizards, and (c) test whether this is reflected in the number of encountered sand lizards.

\section{Materials and methods}

Study site

The study area is located in the inner dunes near Castricum (Fig. 1), in the western part of the Netherlands $\left(52^{\circ} 34^{\prime} 34 \mathrm{~N}\right.$; $\left.4^{\circ} 38^{\prime} 41 \mathrm{E}\right)$. In this area six plots were selected, three grazed and three ungrazed. The grazed area (56.7 ha) has an 


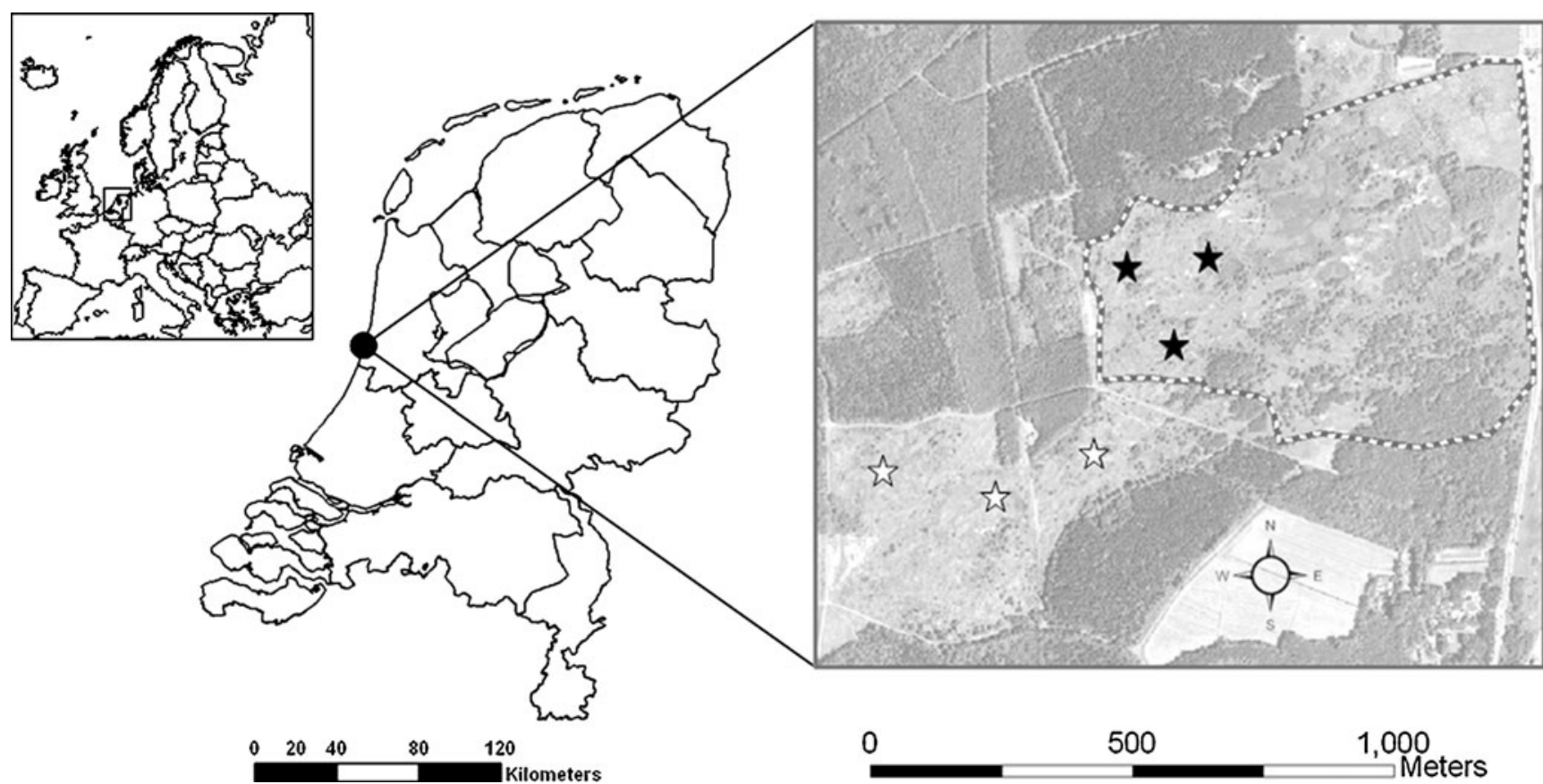

Fig. 1 Map of the Netherlands showing its location within Europe (left). Within the map of the Netherlands the location of the study area near Castricum is shown (middle). On the right an aerial photograph of the study site in the inner dunes near Castricum is shown. The

average grazing intensity of 0.17 Large Livestock Units (LLU) $\cdot$ ha $^{-1} \cdot$ year $^{-1}$. Open range grazing was introduced in 1999 and is done by ponies (year round) and cattle (June to March). It is known that ponies and cattle have a strong diet preference for graminoid species (Lamoot et al. 2005). The choice of plots, which was made on basis of visual effects of grazing in the field, coincides with this preference (Fig. 1). Effectively this diet preference also means that grazing intensity throughout the year likely exceeds the above mentioned grazing intensity. Both grazed and ungrazed plots were similar in size ( 0.5 ha) and geomorphology, and had no management differences up to 1999. All distinguished vegetation structure classes (Table 1) were present in the plots.

\section{Vegetation cover maps}

For the analyses, high resolution aerial photographs were used from three years (Table 2): before RVHD extinction of rabbits grazed area (56.7 ha) is indicated with a dashed line around it and grazed study plots are indicated with black stars and ungrazed plots with white stars

and massive expansion of grasses and shrubs (1987), after rabbit extinction and grass/shrub expansion, but before grazing management (1995) and after four years of grazing management (2003). Aerial photographs from different years were all taken in the beginning of summer, between the end of May and the beginning of July. Differences in vegetation cover due to seasonality are therefore not to be expected. The 1987 and 1995 photographs were scanned and geo-referenced to the already geo-referenced 2003 photos. Ten vegetation structures could be distinguished: sand, sand with algae, sand with mosses and grasses, mosses, grass, dense grass, tussocks, Salix repens, Hippophae rhamnoides and shrub/trees.

ArcGIS, Erdas Imagine 8.x. and Definiens professional 5 were used to prepare images and to produce the vegetation cover maps (Definiens 2006; ESRI 2004; Leica-Geosystems 2004). Images were segmented into polygons using image texture such as differences in colour or shape and compactness or smoothness (Definiens 2006; Geerling et al. 2009).
Table 1 Sand lizard habitat suitability score for coverage of structural vegetation classes within home ranges of sand lizard, classified as optimal configuration (3 points), suboptimal configuration (1 point), unsuitable configuration ( 0 points)

\begin{tabular}{lccccc}
\hline Suitability score & 0 & 1 & 3 & 1 & 0 \\
\hline Structure class & & & & & \\
\hline Sand \& sand with algae & & $0-5 \%$ & $5-20 \%$ & $20-40 \%$ & $>40 \%$ \\
Sand with mosses and grasses \& mosses & & $0-5 \%$ & $5-25 \%$ & $25-40 \%$ & $>40 \%$ \\
Grass \& dense grass \& tussocks & $0-15 \%$ & $15-35 \%$ & $35-50 \%$ & $>50 \%$ \\
Salix repens \& Hippophae rhamnoides & $0-20 \%$ & $20-35 \%$ & $35-55 \%$ & $55-70 \%$ & $>70 \%$ \\
Shrub/trees & & & $0-5 \%$ & $5-15 \%$ & $>15 \%$ \\
\hline
\end{tabular}


Table 2 Aerial photograph type, photographic scale and pixel size. The pixel size of the analogue aerial imagery is based on the digital scan taken from this image

\begin{tabular}{|c|c|c|c|}
\hline & 1987 & 1995 & 2003 \\
\hline Type & $\begin{array}{l}\text { False colour, } \\
\text { analogue }\end{array}$ & $\begin{array}{l}\text { False colour, } \\
\text { analogue }\end{array}$ & $\begin{array}{c}\text { False colour, } \\
\text { digital }\end{array}$ \\
\hline Scale & $1: 5000$ & $1: 2500$ & $1: 2500$ \\
\hline Pixel size & $0.0625 \mathrm{~m}^{2}$ & $0.0625 \mathrm{~m}^{2}$ & $0.0256 \mathrm{~m}^{2}$ \\
\hline
\end{tabular}

After segmentation the maps were classified and a stereoscope (type Wild) was used to verify the polygon outlines and interpret the vegetation structure. Fragstats 3.3 was used to calculate patch size and type (McGarigal and Marks 1995). Patches were divided into 11 size classes $\left(<0.5 \mathrm{~m}^{2}\right.$, 0.5 to $1.5 \mathrm{~m}^{2}, 1.5$ to $3.5 \mathrm{~m}^{2}, 3.5$ to $7.5 \mathrm{~m}^{2}, 7.5$ to $15.5 \mathrm{~m}^{2}$, 15.5 to $31.5 \mathrm{~m}^{2}, 31.5$ to $63.5 \mathrm{~m}^{2}, 63.5$ to $127.5 \mathrm{~m}^{2}, 127.5$ to $255.5 \mathrm{~m}^{2}, 255.5$ to $511.5 \mathrm{~m}^{2},>511 \mathrm{~m}^{2}$ ).

Spatially explicit analysis of habitat suitability for sand lizards

To quantify habitat suitability for sand lizards and temporal changes therein, vegetation cover maps were related to the habitat use of the sand lizard. The initially identified ten vegetation structure classes were aggregated to five vegetation structure classes (Table 1), which have previously been shown to be important habitat elements for sand lizards (House and Spellerberg 1983a; b). The different structure classes were divided on basis of the height of the vegetation (Cooke 1991). Because there were no plants higher than one meter in the class of Salix repens \& Hippophae rhamnoides at the studied plots, these shrubs were kept separate from the shrub/trees class which were all higher than one meter. Note that at different sites and different geographical regions the division between these classes can be different.

A GIS based method was developed to analyse the landscape from a sand lizard's perspective. The model, which uses a moving window analysis, calculated for each GIS raster cell (pixel) the relative coverage of each structure class within a circle with radius of $5.6 \mathrm{~m}$. This translates to an area of $100 \mathrm{~m}^{2}$, fully covering a sand lizard's daily home range (Van Leeuwen and Van de Hoef 1976). Optimal and suboptimal habitat configurations reported by House and Spellerberg (1983a, b), Cooke (1991) and Glandt (1991) were used to score suitability for each structural class coverage (Table 1). Optimal and suboptimal coverage were awarded 3 points and 1 point respectively. Too low or too high coverage of any one structural class was deemed unsuitable and awarded no points. As five structure classes were used, habitat suitability score ranged from 0 (unsuitable) to 15 (optimal). The resulting maps show within-plot spatial variation in habitat suitability and allow evaluation of changes in overall plot scores as well as within-plot spatial shifts through time.

\section{Number of encountered sand lizards}

Sand lizard abundance was studied from April to September 2005. The six plots were censused 9 to 13 times under similar weather and daytime conditions. Visual encounter surveys were done by two people systematically scanning the total plot from one side to the other. The number of encounters and the time spent in a plot were recorded. It was also attempted to catch each encountered lizard. Caught lizards were photographed for individual recognition (Märtens and Grosse 1996) in order to estimate population size. Unfortunately not enough lizards were caught to give a reliable estimation for population size (data not shown). Therefore we only report the number of encountered lizards per manhour per hectare. Although the time spent in each plot during one round was variable depending on the number of encountered lizards, total census effort was comparable between the grazed part (107 h) and ungrazed part (114 h).

\section{Data analysis}

To detect the major changes in both vegetation type and patch size, a Principal Component Analysis (PCA) was performed in Canoco for Windows version 4.0 (Ter Braak and Šmilauer 1998) on the ten vegetation classes subdivided in eleven size classes (110 species) for each plot in each year (total eighteen sites). Preliminary data analysis in Canoco indicated a short gradient length, making PCA the most appropriate ordination technique.

To test for effects of vegetation succession over the years (1987, 1995 and 2003) and management (grazing and no grazing) on habitat suitability for sand lizards, we performed a repeated measures analysis (Anova with Greenhouse-Geisser correction) on the average suitability scores. A $t$-test was used to test for differences in sand lizard numbers between grazed and ungrazed plots.

To illustrate how different vegetation structure classes contributed differently over the three years to the total habitat suitability score, we compared the two most disparate structure classes ("S. repens and H. rhamnoides" and "sand"). For this comparison we calculated the number of pixels making up each habitat suitability score (scores attributed to habitat suitability are derived from Table 1), and the number was then expressed as a percentage coverage (correcting for difference in pixel size between 1987 and 2003 and for differences in total area between plots). Differences in this percentage coverage were tested with Mann-Whitney tests for each habitat suitability score. 


\section{Results}

Changes in vegetation heterogeneity

Patch size and ecotope type distribution differed between grazed and ungrazed plots in 1987, 1995 and 2003 (Figs. 2 and 3). Both grazed and ungrazed plots exhibited a change in configuration from small (1-4) sand and moss dominated patches in 1987 to larger (6-8) grass and shrub dominated patches in 2003 (Fig. 2). From 1987 to 2003 the grazed and ungrazed plots exhibited similar changes in class cover; shrub classes (H. rhamnoides; $S$. repens and other shrubs and trees) and dense grasses increased, whereas moss and sand classes (sand; sand with algae and sand with mosses and grasses) decreased. For the ungrazed plots, most pronounced changes occurred after 1995, which coincide with an increase in woody classes (Salix repens, Hippophae rhamnoides and shrub/trees) and patch size. In the grazed plots this shift had already occurred between 1987 and 1995 before grazing was introduced.

The average cover of the different vegetation structure classes was calculated (Fig. 3), plots of the same year and treatment were grouped because of high similarities (Fig. 2). In both treatments a 30-40\% moss cover disappeared between 1987 and 2003, sand dominated patches decreased by approximately $60 \%$ and a $40 \%$ cover of grasses and woody species in 1987 increased to more than $90 \%$ in 2003 . Small differences between treatments included a higher cover for the different classes of sand (sand; sand with algae and sand with mosses and grasses) and a lower moss cover in the ungrazed plots of 1987. In addition, stands of $H$. rhamnoides occurred only in the ungrazed plots.

\section{Sand lizard habitat suitability}

Whole plot average values for sand lizard habitat suitability scores did not differ between years and treatments (Table 3, Anova with Greenhouse-Geisser correction, $p>0.05$ ). In contrast, on a smaller scale (within plots), large spatial shifts in habitat suitability occurred during the research period (Fig. 4). The occurrence of these large within-plot spatial changes without the co-occurrence of an overall change between year and treatment result from a spatial inversion of how suitable patches are distributed in the plot (Fig. 4): low quality patches became more suitable, whilst patches of intermediate and high quality became less suitable over time (Table 4). These shifts in habitat suitability correspond with an increase of $S$. repens and $H$.
Fig. 2 Principal component analysis of patch size and ecotope class distribution through time. The figure shows changes and their explaining factors from 1987 (white) via 1995 (grey) to 2003 (black) from the three grazed (rounds) and three ungrazed (triangles) plots. Numbers $(1-11)$ represent size classes going from $1(<1 \mathrm{~m} 2)$ to 11 $(>511.5 \mathrm{~m} 2)$ and are explained in the text

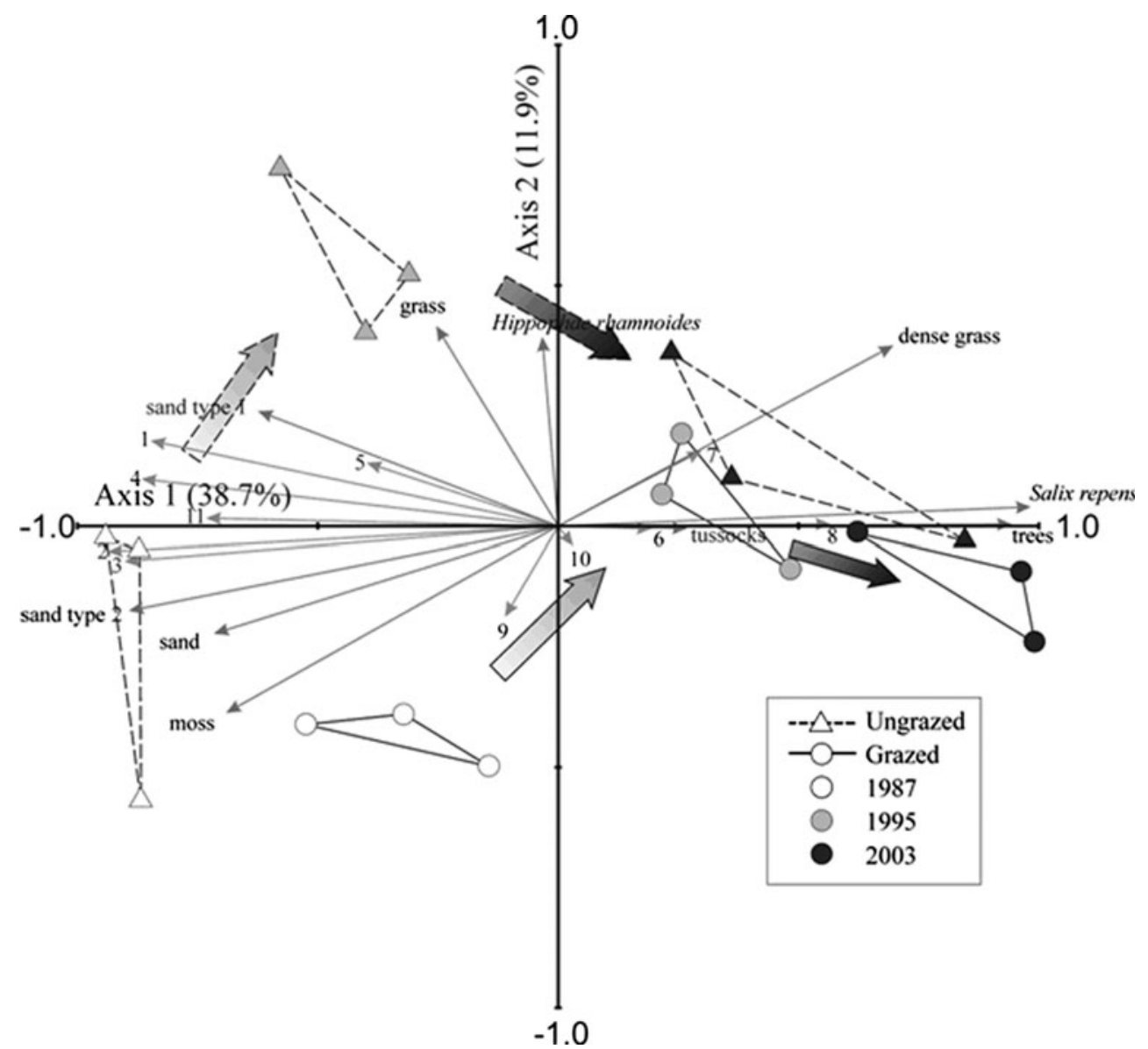


Fig. 3 Average cover $(\% ;$ mean; $n=3)$ of the different ecotope classes through time for grazed and ungrazed plots

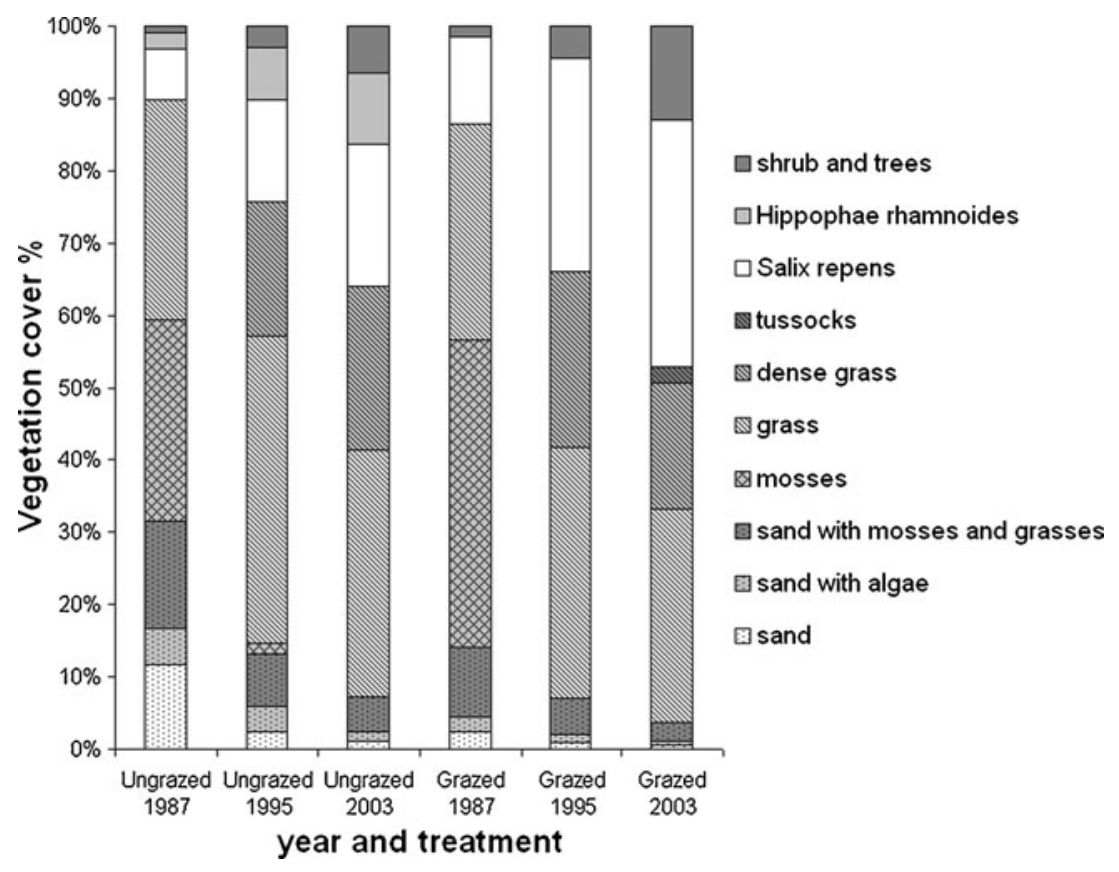

rhamnoides and a decrease in sand coverage (Fig. 5, MannWhitney, $p<0.05$ ).

Number of encountered sand lizards

The average number of encountered sand lizards per manhour per hectare in ungrazed and grazed plots were $4.5(\mathrm{SE}=$ $0.4)$ and $5.3(\mathrm{SE}=0.5)$ respectively and did not differ between treatments ( $T$-test; $p>0.05$ ).

\section{Discussion}

Grazing and heterogeneity

Despite the implementation of grazing management in 1999, habitat development in terms of patch size and type from 1987 to 2003 was similar in all plots. The vegetation changed from being dominated by sand and moss in 1987, towards high cover of dense grass and shrub in 2003. Simultaneously, mean patch size increased (Figs. 2 and 3). Grazing did reduce the height of dense grass vegetation (pers. field obs.), but this was not detectable on aerial photographs. Although this may have slowed down expansion of tall grasses and shrubs, it appears insignificant compared to the autonomous vegetation succession in the area.

A variety of grazing effects is reported from other studies (Adler et al. 2001), leading to increases as well as decreases of spatial heterogeneity. De Bonte et al. (1999) report a decrease of dense grass in favour of sand, moss covered sand and low grass after five years of grazing with similar grazers and grazing pressure in a different dune area
(Meijendel, the Netherlands). In another dune area (Zepeduinen, the Netherlands) a similar grazing intensity resulted in lower grass vegetation and increased structural heterogeneity, but similar to our results grass encroachment was not halted completely (Kooijman and Van der Meulen 1996). Grazer identity and intensity, soil properties and spatial scale of the study area can play a crucial role in explaining the different outcomes across the various studies in terms of the response in plant species composition and vegetation heterogeneity (Kohyani et al. 2008). This provides a cautionary note when comparing our results from a Dutch dune area to grazing effects in other dune areas inside and outside the Netherlands.

The failure of grazing management to counteract the expansion of grasses and shrubs in this study could be caused by the short period since grazing was introduced. Another important factor influencing the minor effect on tall grass cover might be the used grazing intensity. This intensity falls within the range of those used in other studies, it is however on the low to moderate end of the spectrum of applied stocking rates in similar habitats; e.g. between 0.15 and $0.46 \mathrm{LLU} \cdot \mathrm{ha}^{-1}$.year $^{-1}$ on Belgian dune grasslands (Kohyani et al. 2008), between 0.12 and 0.49

Table 3 Mean values and standard errors (SE) of sand lizards habitat suitability score through time. There were no significant differences in lizard habitat suitability scores (Anova with Greenhouse-Geisser correction, $p>0.05$ ) between years and treatment

\begin{tabular}{llll}
\hline & 1987 & 1995 & 2003 \\
\hline Ungrazed & $6.74(\mathrm{SE}=0.10)$ & $6.97(\mathrm{SE}=0.20)$ & $6.51(\mathrm{SE}=0.24)$ \\
Grazed & $6.51(\mathrm{SE}=0.25)$ & $6.83(\mathrm{SE}=0.17)$ & $6.71(\mathrm{SE}=0.17)$ \\
\hline
\end{tabular}




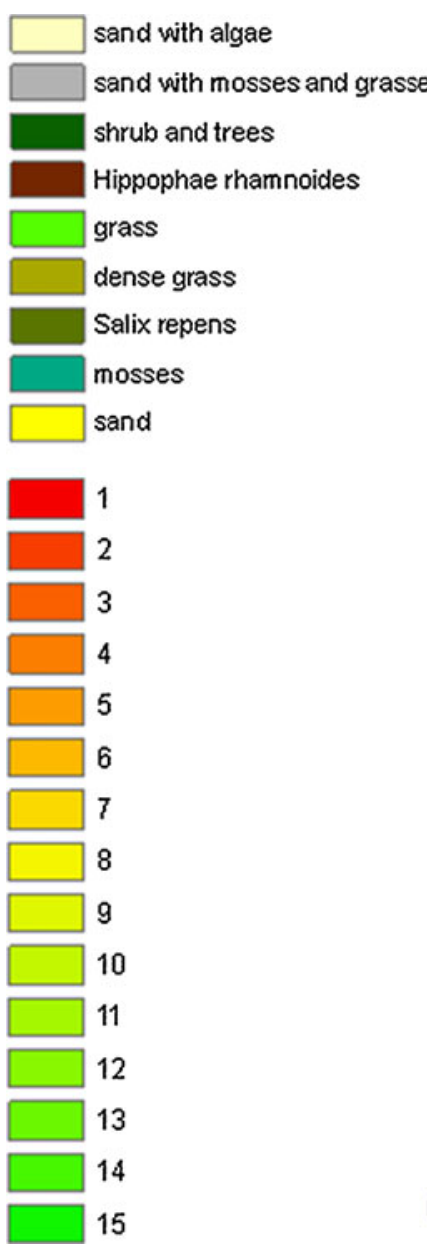

Fig. 4 A selection of plot cover maps (left) accompanied by their habitat suitability maps (right). Habitat suitability scores vary between 1 and 15, 1 representing unsuitable spots and 15 very suitable spots.

LLU $\cdot \mathrm{ha}^{-1} \cdot$ year $^{-1}$ on sand dune vegetation communities in the UK (FitzGibbon et al. 2005) and between 0.1 and 0.25 LLU $\cdot \mathrm{ha}^{-1} \cdot$ year $^{-1}$ on lowlands heathland in the UK (Symes and Day 2003). Other likely explanations are the combined effects of high levels of airborne nitrogen deposition and a very low natural grazing regime by rabbits, whose

Table 4 Total habitat suitability class change from 1987 to 2003 (\%; means; $n=6)$. Total suitability scores are divided into three classes: 11-15 (++), 6-10 (+) and 1-5 (-). To facilitate interpretation, grey area represent no change, black represent a negative change and white
1987

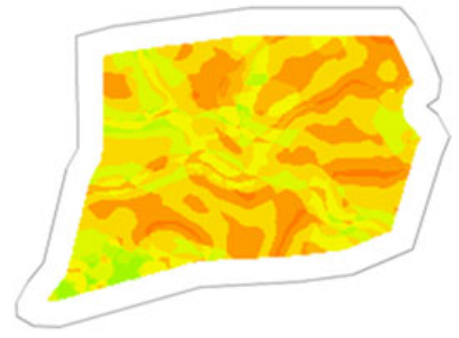

1995

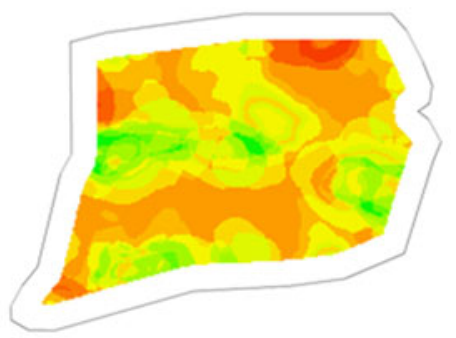

2003

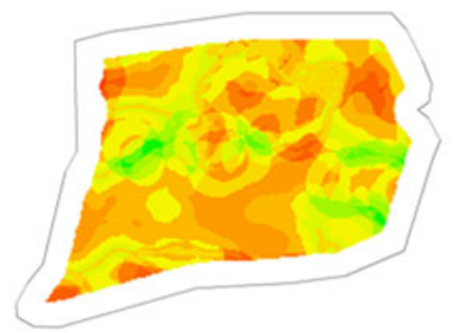

Due to the window of $5.6 \mathrm{~m}$ radius (representing a lizard's home range) used in the habitat suitability analysis, the suitability maps are $5.6 \mathrm{~m}$ smaller on the side to prevent inclusion of no-data points

populations have decreased in numbers up to $90 \%$ between successive study years (1990-2003) in the whole of the Netherlands (Drees et al. 2009). Since changes in vegetation heterogeneity were most apparent when comparing plots over time, rather than comparing between grazed and ungrazed plots, we will focus the discussion on the effects

represent a positive change in suitability class. For instance, out of all the poor $(-)$ habitat patches, which constituted about a third $(34.7 \%)$ of the total area in 1987, some remained poor (37\%), most improved $(60 \%)$, while a tiny fraction $(3 \%)$ became very good $(++)$

\begin{tabular}{l|ccc}
\hline & $1987-$ & $1987+$ & $1987++$ \\
& $(34.7 \%$ of total area $)$ & $(63.3 \%$ of total area $)$ & $(\mathbf{1 . 9 8 \% ~ o f ~ t o t a l ~ a r e a ) ~}$ \\
\hline $2003-$ & $37 \%$ & $31 \%$ & $31 \%$ \\
$2003+$ & $60 \%$ & $63 \%$ & $65 \%$ \\
$2003++$ & $3 \%$ & $6 \%$ & $4 \%$ \\
\hline
\end{tabular}


Fig. 5 The number of pixels contributing to each habitat suitability score (scores attributed to habitat suitability are derived from Table 1), expressed as average $\%$ cover (means \pm standard error; $n=6$ ). The two most disparate structure classes are shown: $S$. repens and $H$. rhamnoides (woody vegetation, a) and sand (no vegetation, b). Years are shown separately 1987 (grey), 1995 (black) and 2003 (white). Asterisks show significant differences across years for a given class (Mann-Whitney, $p<0.05$ )
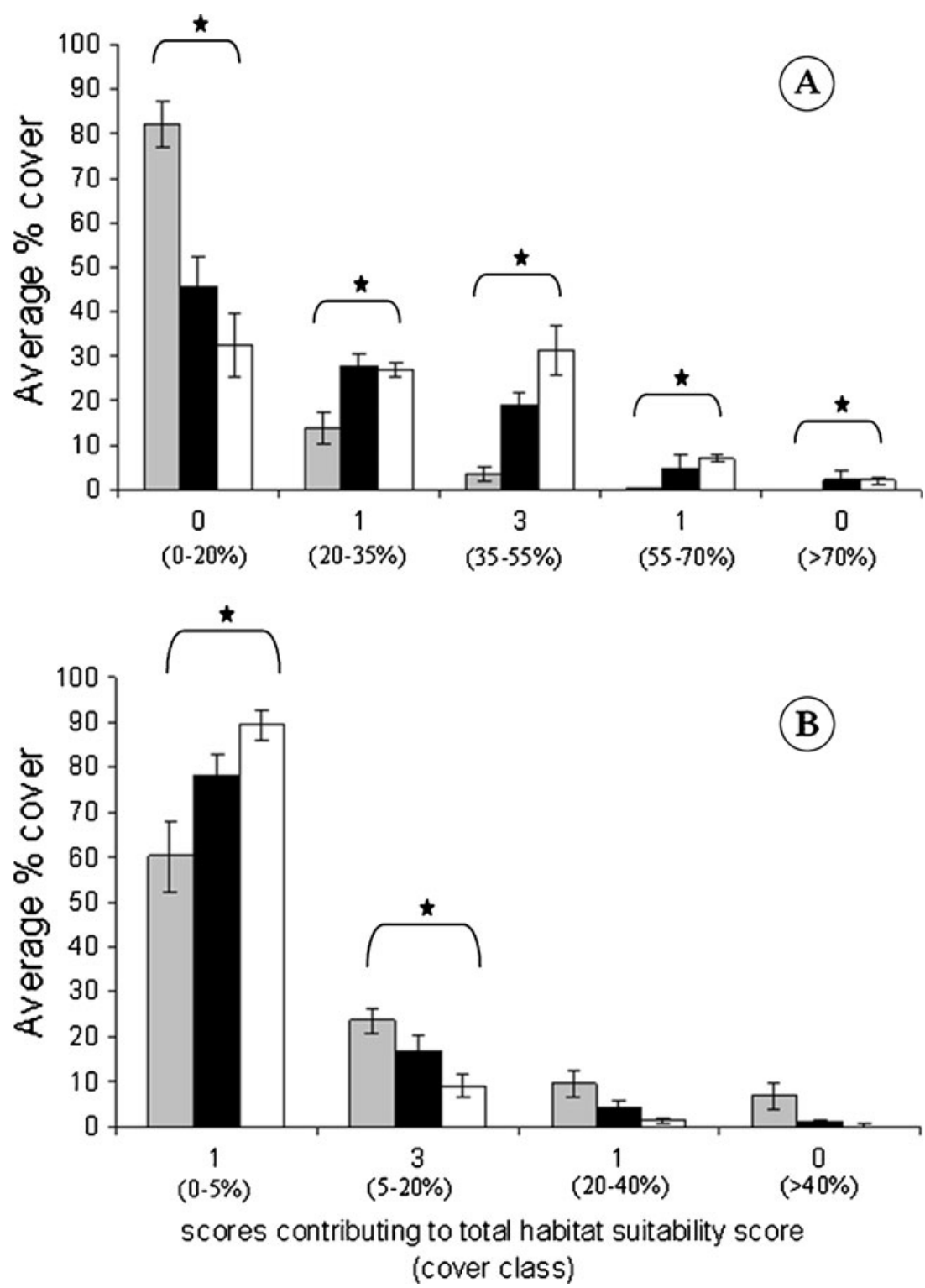

of autonomous vegetation succession in relation to habitat suitability of sand lizards.

\section{Sand lizard habitat quality}

Sand lizards require a structurally complex habitat with combinations of different patches for thermoregulation, foraging, hiding, hibernation and egg deposition (Edgar et al. 2010; House and Spellerberg 1983a; b) and their numbers have been shown to decline when heterogeneity decreases (De Bruyn 1997; Jackson 1979). Despite pronounced within-plot spatial changes in heterogeneity (Fig. 4), average habitat suitability per plot neither changed in time, nor differed between grazed and ungrazed plots. In addition, field surveys in 2005 confirm the absence of differences in habitat suitability, showing no differences in sand lizard encounters between grazed and ungrazed plots. The absence of differences in sand lizard numbers when habitat suitability is comparable would also suggest there is not a strong, direct impact of the current grazing intensity (0.17 LLU ha $^{-1}$ year $\left.^{-1}\right)$ on sand lizards. This agrees with the findings of Edgar et al. (2010), who suggest that great negative effects on sand lizards were not to be expected because stocking rates were below $0.2 \mathrm{LLU} \mathrm{ha}^{-1}$ year ${ }^{-1}$, which is seen as a stocking rate from where negative effects are expected. The absence of differences in sand lizard numbers would seem to question the validity of the sand lizard as an indicator species for heterogeneity. However, in contrast to the stability of habitat suitability scores averaged over entire plots, pronounced changes of within-plot spatial differences in habitat suitability scores were observed. Sand lizards may thus be valid indicator species on smaller 
spatial scales. Spatial changes in habitat suitability partly resembled an inversion, with highly suitable locations deteriorating and unsuitable locations becoming more suitable through the years. This deviates from the more commonly observed pattern of habitat change, where the most suitable locations also remain suitable for the longest time, providing refugia in the face of habitat deterioration.

One could argue that the change of suitable location into unsuitable locations and vice versa is characteristic for dynamic dry coastal dunes and that despite shifting vegetation mosaics a status quo is preserved of suitable patches being present somewhere in the landscape. However, the relative contribution of the different structure classes to the sand lizard habitat suitability showed strong directional changes. In 1987 habitat suitability was constrained by the low cover of shrub (Salix repens or Hippophae rhamnoides), while patches of open sand and low vegetation were too large. With a strong increase of shrubs together with a decrease in open sand and mosses, limitation of necessary structural elements hardly occurred in 2003, but instead habitat suitability was limited by low coverage of open sand. With ongoing succession and unchanged management, sand lizard habitat suitability is expected to decrease due to a further loss of open sand and pioneer vegetation, as well as an increase of coverage of tall grass, shrubs and trees. Three problems can be implicated. First, sand lizards require at least $1-1,5 \mathrm{~m}^{2}$ of open sand per hectare for oviposition (Strijbosch 1987) and maintaining $1-10 \%$ of bare soil, recommended for a good sand lizard habitat (JNCC 2009), can prevent these sites from becoming limiting. Second, loss of variation in vegetation structure reduces possibilities for thermoregulation, a problem documented for the closely related common lizard Zootoca vivipara (Herczeg et al. 2006). Third, a denser and more homogeneous vegetation may harbour lower prey densities, prey visibility and decrease foraging activity.

\section{Practical implications}

From the differences between whole-plot and within-plot habitat suitability for sand lizards, it is clear that the indicator function for heterogeneity of the sand lizard is scale-dependant. At the local (within-plot) scale level, the distribution of sand lizards could probably be a useful indication of within-plot habitat heterogeneity. Changes in within-plot habitat heterogeneity occurring over several years could thus be effectively traced through fine scaled sand lizard distribution monitoring. This is also recommended by Offer et al. (2003) who suggests that a good monitoring programme of reptiles and vegetation structure is essential as a precaution for negative effects in areas where grazing is recommended. At the regional (betweenplot) scale level, habitat suitability has proven resistant to changes in habitat heterogeneity until present. It is expected to decrease with further vegetation succession and loss of open sandy patches. Changes in sand lizard population size at this scale most likely occur only after long ongoing and chronic habitat degradation, limiting its use as an early warning indicator. The abundance of an indicator species is ideally linked with natural landscape heterogeneity, with the species operating on a scale which is in accordance with natural landscape dynamics. As it will often be impossible to find a species fitting this profile, a multi-species approach is preferred with species responding to habitat heterogeneity at different scales (local to regional) (Maes and Van Dyck 2005; Verberk 2011).

The extensive grazing regime applied in our study area did not halt the expansion of grasses and shrubs and the loss of heterogeneity. Increase of grazing pressure can however have adverse effects on reptiles (Edgar et al. 2010) and other fauna of nutrient-poor grasslands, as also shown for snails (Boschi and Baur 2007). Management of dune areas should aim at reversing this encroachment and restoring habitat heterogeneity at multiple scales, ranging from local sandy patches, for a species as the blue-winged grasshopper Oedipoda caerulescens, to a mosaic of different vegetation patches for butterflies as the grayling Hipparchia semele (Maes and Bonte 2006) and insectivorous birds as the red-backed shrike Lanius collurio (Van Duinen et al. 2004). The key large scale management tool to achieve these goals is a sustainable reactivation of aeolian dynamics. Spatial differences in aeolian dynamics can create a fine scaled mosaic of patches with differences in soil development and vegetation succession beneficial for many plant and animal species (De Bruyn 1997; Doing 1995; Ranwell 1972). This is also essential for sand lizard conservation providing a suitable habitat with combinations of different patches for thermoregulation, foraging, hiding, hibernation and egg deposition (Edgar et al. 2010; Glandt 1991; House et al. 1980; House and Spellerberg 1983a). On a smaller scale, extensive grazing, emulation of grazing through mowing and emulation of aeolian dynamics through sod cutting are management practices which are in use nowadays. These practices, either separate or combined, may prove suitable for reversing encroachment and restoring heterogeneity of coastal dunes, but their planning will require a differentiation of measures in space and time (Edgar et al. 2010).

\section{Conclusions}

The use of a habitat suitability model has proven to be a useful tool to functionally interpret changes in dry coastal dune heterogeneity from an animal's perspective. Average habitat suitability proved unresponsive to changes in habitat hetero- 
geneity until present but is expected to decrease with further vegetation succession and loss of open sandy patches. Monitoring the distribution of sand lizards as an early warning system will be more suitable for documenting habitat heterogeneity on a smaller scale. The grazing intensity used in this research did not halt expansion of grasses and woody species. Large scale reactivation of aeolian dynamics and small scale emulation of these processes are deemed most promising to offset the negative effects of encroachment. Habitat suitability models such as these can help site managers focus management efforts by identifying essential habitat elements. To fully capture the natural landscape dynamics we recommend expanding habitat suitability models to encompass multiple species operating on different scale levels and differing in their essential habitat elements.

Acknowledgments We thank the Provincial Water company North Holland for supporting and funding this study, especially Rienk Slings and Hubert Kivit for their assistance during the research. Henk Strijbosch and Ravon for their expert judgement and access to their literature database. Special thanks to Gemma Rutten for her assistance in collecting the lizard encounter data during field work. Finally, the paper improved by constructive comments of an anonymous referee.

Open Access This article is distributed under the terms of the Creative Commons Attribution Noncommercial License which permits any noncommercial use, distribution, and reproduction in any medium, provided the original author(s) and source are credited.

\section{References}

Adler PB, Raff DA, Lauenroth WK (2001) The effect of grazing on the spatial heterogeneity of vegetation. Oecologia 128:465-479

Bonte D, Maelfait J-P, Hoffman M (2000) The impact of grazing on spider communities in a mesophytic calcareous dune grassland. $\mathrm{J}$ Coast Conserv 6:135-144

Bonte D, Criel P, Vanhoutte L, Van Thournout I, Maelfait J-P (2004) The importance of habitat productivity stability and heterogeneity for spider species richness in coastal grey dunes along the North Sea and its implications for conservation. Biodivers Conserv 13:2119-2134

Boschi C, Baur B (2007) The effect of horse cattle and sheep grazing on the diversity and abundance of land snails in nutrient-poor calcareous grasslands. Basic Appl Ecol 8:55-65

Cooke AS (1991) The habitat of sand lizards Lacerta agilis at Merseyside. English Nature research \& survey in nature conservation 41

Council directive 92/43/EEC of May 21 (1992) on the conservation of natural habitats and of wild fauna and flora, http://ec.europa.eu/ environment/nature/legislation/habitatsdirective. Accessed on Nov 2011

De Bonte AJ, Boosten A, Van der Hagen HGJM, Sýkora KV (1999) Vegetation development influenced by grazing in the coastal dunes near The Hague The Netherlands. J Coast Conserv 5:59-68

De Bruyn GJ (1997) Animal communities in Dutch dunes. In: Van der Maarel E (ed) Dry coastal ecosystems: general aspects. Elsevier, Amsterdam, pp 361-386

Definiens (2006) Definiens Professional 5 User Guide Definiens. Munchen
Dennis P, Aspinall RJ, Gordon IJ (2002) Spatial distribution of upland beetles in relation to landform vegetation and grazing management. Basic Appl Ecol 3:183-193

Doing H (1995) Landscape ecology of the Dutch coast. J Coast Conserv 1:145-172

Drees JM, Olff H (2001) Rabbit grazing and rabbit counting. In: Houston JA, Edmonson SE, Rooney PJ (eds) Coastal dune management Shared experience of European conservation practice. Liverpool University Press, Liverpool, pp 86-95

Drees JM, Dekker JJA, Wester L, Olff H (2009) The translocation of rabbits in a sand dune habitat: survival, dispersal and predation in relation to food quality and the use of burrows. Luntra 52:109-122

Edgar P, Foster J, Baker J (2010) Reptile habitat management handbook. Amphibian and Reptile Conservation, Bournemouth

ESRI (2004) ArcGIS 91 Environmental Systems Research Institute Red lands. California

FitzGibbon C, Albon S, Robinson P (2005) The effects of a mixed grazing regime on sand dune vegetation communities at Braunton Burrows, Devon. English Nature Research Reports, No 637

Geerling GW, Ragas AMJ, Leuven RSEW, van Den Berg JH, Breedveld M, Liefhebber D (2006) Succession and rejuvenation in floodplains along the river Allier (France). Hydrobiologia 565 (1):71-86

Geerling GW, Vreeken-Buijs MJ, Jesse P, Ragas AMJ, Smits AJM (2009) Mapping river floodplain ecotopes by segmentation of spectral (CASI) and structural (LiDAR) remote sensing data. River Res Appl 25(7):795-813

Gibson CWD, Brown VK, Losito L, McGavin GC (1992) The response of invertebrate assemblies to grazing. Ecography $15: 166-176$

Glandt D (1991) The vegetation structure preferred by the sand lizard (Lacerta agilis) and the common lizard (Lacerta vivipara) in an experimental outdoor enclosure. Acta Biol Benrodis 3:79-86

Gusafson EJ (1998) Quantifying landscape spatial patterns: what is the state of the art? Ecosystems 1:143-156

Herczeg G, Gonda A, Saarikivi J, Merila J (2006) Experimental support for the cost-benefit model of lizard thermoregulation. Behav Ecol Sociobiol 60:405-414

Hopkins J, Radley G (1998) Sand dunes and the Habitat directive: preparation of the UK national list. In: Houston JA, Edmondson SE, Rooney PJ (eds) Coastal dune management shared experience of European conservation practice. Liverpool University Press, Liverpool, pp 283-301

House MS, Spellerberg IF (1983a) Ecology and conservation of sand lizard (Lacerta agilis) habitat in southern England. J Appl Ecol 20:417-437

House MS, Spellerberg IF (1983b) Comparison of Lacerta agilis habitats in Britain and Europe. Br J Herpetol 6:305-308

House MS, Taylor PJ, Spellerberg IF (1980) Patterns of daily behaviour in two lizard species Lacerta agilis $L$ and Lacerta vivipara Jacquin. Oecologia 44:396-402

Huston M (1979) A general hypothesis of species diversity. Am Nat 113:81-101

Jackson HC (1979) The decline of sand lizard Lacerta agilis L population on the sand dunes of the Merseyside coast England. Biol Conserv 16:177-193

JNCC (2009) Common standards monitoring guidance for lowland heathland. Version February 2009, ISSN 1743-8160

Jones MLM, Wallace HL, Norris D, Brittain SA, Haria S, Jones RE, Rhind PM, Reynolds BR, Emmett BA (2004) Changes in vegetation and soil characteristics in coastal sand dunes along a gradient of atmospheric nitrogen deposition. Plant Biol 6:598605

Kerr JT, Southwood TRE, Cihlar J (2001) Remotely sensed habitat diversity predicts butterfly species richness and community similarity in Canada. PNAS 98(20):11365-11370 
Ketner-Oostra R, Sýkora KV (2004) Decline of lichen diversity in calcium-poor coastal dune vegetation since the 1970s related to grass and moss encroachment. Phytocoenologia 34:521-549

Kohyani PT, Bossuyt B, Bonte D, Hoffmann M (2008) Grazing as a management tool in dune grasslands: evidence of soil and scale dependence of the effect of large herbivores on plant diversity. Biol Conserv 141:1687-1694

Kooijman AM, Van der Meulen F (1996) Grazing as a control against 'grass-encroachment' in dry dune grasslands in the Netherlands. Landsc Urban Plann 34:323-333

Kooijman AM, Dopheide JCR, Sevink J, Takken I, Verstraten JM (1998) Nutrient limitations and their implications on the effects of atmospheric deposition in coastal dunes; lime-poor and limerich sites in the Netherlands. J Ecol 86:511-526

Lamoot I, Meert C, Hoffmann M (2005) Habitat use of ponies and cattle foraging together in a coastal dune area. Biol Conserv 122:523-536

Leica-Geosystems (2004) Erdas Imagine 87 Erdas Inc. Atlanta, Georgia

Maes D, Bonte D (2006) Using distribution patterns of five threatened invertebrates in a highly fragmentated dune landscape to develop a multispecies conservation approach. Biol Conserv 133:490499

Maes M, Van Dyck H (2005) Habitat quality and biodiversity indicator performances of a threatened butterfly versus a multispecies group for wet heathlands in Belgium. Biol Conserv 123:177-187

Märtens B, Grosse W-R (1996) Gotografische Wiedererkennung bei Zauneidechsen (Lacerta agilis L., 1758). Die Eidechse 7:1-6

McGarigal K, Marks B (1995) FRAGSTATS: Spatial analysis program for quantifying landscape structure PNW-GTR-351 USDA Forest Service

Offer D, Edwards M, Edgar P (2003) Grazing heathland: a guide to impact assessment for insects and reptiles. English Nature Research Reports No. 497. English Nature, Peterborough

Pöyry J, Luoto M, Paukunen J, Pykälä J, Raatikainen K, Kuussaari M (2006) Different responses of plants and herbivore insects to a gradient of vegetation height: an indicator of the vertebrate grazing intensity and successional stage. Oikos 115:401-412

Provoost M, Laurence M, Jones M (2009) Changes in landscape and vegetation of coastal dunes in northwest Europe: a review. J Coast Conserv. doi:10.1007/s11852-009-0068-5
Ranwell DS (1963) Newborough Warren Anglesey III Changes in the vegetation on parts of the dune system after the loss of rabbits by myxomatosis. J Ecol 51:385-395

Ranwell DS (1972) Ecology of salt marshes and sand dunes. Chapman and Hall, London

Stoutjesdijk P, Barkman JJ (1992) Microclimate vegetation and fauna. OPULUS Press AB, Knivsta

Strijbosch H (1987) Nest site selection of Lacerta agilis in the Netherlands. Proceedings of the $4^{\text {th }}$ Ordinary General Meeting of the Societas Europaea Herpetologica. University of Nijmegen, Faculty of Sciences, Nijmegen, The Netherlands

Stumpel AHP, 2004 Reptiles and amphibians as targets for nature management. Alterra Scientific Contributions 13. Alterra, Wageningen

Symes N, Day J (2003) A practical guide to the restoration and management of Lowland Heathland. RSPB, Sandy

Ter Braak CJF, Šmilauer P (1998) CANOCO reference manual and user's guide to canoco for windows: software for canonical community ordination (version 4). Microcomputer power, Ithaca

Tews J, Brose U, Grimm V, Tielbörger K, Wichmann MC, Schwager M, Jeltsch F (2004) Animal species diversity driven by habitat heterogeneity/diversity: the importance of keystone structures. J Biogeogr 31:79-92

Van Duinen GA, Beusink P, Nijssen M, Esselink H (2004) Broed- en voedselecologie van de Grauwe Klauwier in intacte kustduinen De Kleine Junikever als schakel in het voedselweb. Rapport Stichting Bargerveen, Nijmegen

Van Leeuwen BH, Van de Hoef JCM (1976) Onderzoek naar de oecologie en populatie-dynamica van de zandhagedis (Lacerta agilis $L$ ) in de duinen van Oostvoorne. Rapport Rijksinstituut voor Natuurbeheer, Leersum

Veer MAC, Kooijman AM (1997) Effects of grass-encroachment on vegetation and soil in Dutch dry dune grasslands. Plant Soil 192:119-128

Verberk WCEP (2011) Gidssoorten wijzen de weg naar herstel. De Levende Natuur 112:152-156

Verberk WCEP, van Duinen GA, Brock AMT, Leuven RCEW, Siepel $\mathrm{H}$, Verdonschot PFM, van der Velde G, Esselink H (2006) Importance of landscape heterogeneity for conservation of aquatic macroinvertebrate diversity in bog landscapes. J Nat Conserv 14:78-90

WallisDeVries MF, Raemakers I (2001) Does extensive grazing benefit butterflies in coastal dunes. Restor Ecol 9:179-188

Wiens JA (1989) Spatial scaling in ecology. Funct Ecol 3:385-397 